\title{
The existence of local wisdom through community protection unit (satlinmas) as the street-level bureaucrat in community security, orderliness and tranquility in Surakarta city
}

\author{
Joko Pramono, Wulan Kinasih, and Johan Bhimo Sukoco \\ Department of Public Administration, Universitas Slamet Riyadi Surakarta \\ johanbhimo@yahoo.co.id
}

\begin{abstract}
The feeling of secure is basic service obligatorily fulfilled by every state to its citizens. To give security protection, Indonesian government establishes Satuan Perlindungan Masyarakat or Community Protection Unit (thereafter called Satlinmas). Satlinmas, as a street-level bureaucrat, serves to help create security, orderliness, and tranquility of community. It is also the manifestation of New Public Service involving the community in creating the feeling of secure in respective environment. One of local wisdom forms represented in Satlinmas is life philosophy "sepi ing pamrih rame ing gawe" (expecting less reward, and working more) and "nguwongke uwong", meaning that humanizing human being during undertaking the duty. It is in line with the fulfillment of secure feeling by government as mentioned in Human Governance.

This research will study the characteristics of Street-level Bureaucrat according to Lipsky (1969) including: routine interaction with community, occupation independency and potential impact on the community. This study was a descriptive qualitative research. Techniques of collecting data used were interview, observation, and document analysis. The informants were selected using purposive sampling technique. Data validation was carried out using data triangulation technique, while data analysis using interactive model of analysis.
\end{abstract}

Keywords: Street-level Bureaucrats, Local Wisdom, Satlinmas, Security and Orderliness

\section{Introduction}

The feeling of secure is basic service obligatorily fulfilled by every state to its citizens. Article 12 of Law Number 23 of 2014 about Local Autonomy states that obligatory government affairs related to basic service include education; health; public work and spatial layout; people housing and settlement area; tranquility, public orderliness and society protection; and social aspects. Considering this regulation, every area obligatorily provides service to tranquility, public orderliness and society protection based on the Standard Minimum Service specified.

The organization of security service has been governed in Republic of Indonesia's Constitution. Article 30 clause 1 of 1945 Constitution states that: "every citizen is entitled to and should participate obligatorily in state defense and security effort". The purpose of Article 30 clause 1 of 1945 Constitution is to explain that every Indonesian citizen has equal right, the right to participate in maintaining the state defense and security. It means that citizens are required to participate in the attempt of defending the state, and creating the security from any annoyance and threat, either domestically or from foreign countries. Considering the elaboration above, defense and security is not only the responsibility of TNI 
and POLRI but also that of citizens called Whole People Defense and Security System (Sistem Pertahanan Keamanan Rakyat Semesta, thereafter called Sishankamrata).

The manifestation of Sishankamrata in the society is the establishment of Satlinmas as the society component cooperating with TNI and POLRI in realizing security, orderliness, and community protection (kamtibmas). Satlinmas plays a very important role in supporting security, orderliness, and community protection. Services in this security and orderliness are in line with New Public Service paradigm. New Public Service paradigm focuses on citizen participation and community building. Citizen participation is viewed as the element that should exist in the policy implementation in democratic system. Through this process, citizens feel being involved in government process and not only require the government to satisfy their interest. Organization becomes a public space, in which citizens and administrator with different perspective acts on collectively for the sake of the public goodness. Interaction and engagement with citizens gives objective and meaning to the public service (Denhard \& Denhard, 2003).

Satlinmas plays strategic role and function in helping TNI and POLRI implement environment security and orderliness and in the attempt of reducing and coping with natural and social disasters and maintaining the possibility of dealing with and anticipating security disturbances. Community Protection Unit (Satlinmas) is Street-Level Bureaucrats in realizing Community Security and Orderliness (Kamtibmas), because they are the lowest level of this function implementation. Street-level bureaucrats are the frontline workers or policy implementers in government agencies" (Libsky: 1969). Satlinmas (community protection unit) relates directly to community. The members of Satlinmas ideally abide in every Neighborhood (Rukun Tetangga), as the smallest unit of organization in community. Every member has responsibility of providing service at that level. The presence of Satlinmas is expected to facilitate the detection of problems existing in the society and use more appropriate approach to solve the problem. Furthermore, Libsky (1969) suggests that street level bureaucrats should be fair or just; the fair or just street level bureaucrats will implement the rule well and will not provide discriminative service. In this case, Satlinmas maintain the public's trust in the assignment given by providing service to all classes of society. Satlinmas as the part of local regulation enforcer gives the community an understanding more humanly and using communicative approach. The enforcement of local regulation is implemented comprehensively to the community regardless their background

Satlinmas as Street-level Bureaucrats relating directly to community needs an appropriate approach, thereby is more acceptable to community. The measure taken by Satlinmas here is to make local values the rationale in doing their job. Local wisdom is the form of traditional mechanism consisting of three basic dimensions: cultural potency dimension, method and approach dimension maintaining wisdom and trust, and objective dimension emphasizing on harmony, balance, and life continuity (Geriya, 2004). Keraf in Marfai (2012) says that local wisdom is related to cultural knowledge, awareness, and practice about human beings, nature, and insight into the relationship between residents of ecological community. As such, local ecology becomes a means for Street level bureaucrats to provide service to the society.

Considering the background explain above, this study explores the characteristics of Satlinmas as Street level bureaucrats and local wisdom always assumed by Satlinmas as 
Street level bureaucrats in maintaining its relationship with community in Surakarta. This research is conducted based on Lipsky (1969) arguing that the characteristics of Street level bureaucrats are, among others: routine interaction with community, occupation independency and potential impact on the community. This research was taken place in Surakarta City. This city is selected because it has achieved the first champion in Satlinmas competition at province level. The informants of research were selected using purposive sampling technique. The informants included Satpol PP (Public Order Enforcers), Lurah (Village Head), platoon commander of Satlinmas, members of satlinmas, and local people. The data of research was collected through interview, observation, and documentation. Interview was conducted by giving open-ended question about activities conducted by Satlinmas in the attempt of executing their duty, the attempt taken in building interaction and communication with community, Satlinmas' independence, and community's response to Satlinmas. The data obtained was then analyzed using an interactive model of analysis. Data validation was carried out using triangulation technique. Triangulation was conducted by comparing all data resulting from interview, observation, and documentation with theory, and by conducting discussion. The results of this study are expected to provide an overview of the importance of local values that must be owned by stret level bereucrats.

\section{Literature Review}

Street level bureaucrats play an important role in providing service to community. The bureaucrat at this level deals with service users directly, thereby understanding better the problems the community encounters. Nawawi (2007) states that public service at street level bureaucrats is front desk service. It means that the service at street level bureaucrats is a very important thing and the first gate of service. As the first gate of service, Street level bureaucrats represent the quality of service provided. It is in line with Libsky (1969) stating that "Street-level bureaucrats are the frontline workers or policy implementers in government agencies". Street level bureaucrats are also the front guard in the policy implementation. This research employed Libsky's Street-Level Bureaucrats theory to analyze characteristics in Satlinmas as the form of Street-level Bureaucrats in organizing safety and orderliness within society.

Satlinmas as the form of Street-level Bureaucrats have some characteristics getting them closer to community. Libsky (1969) mentions 3 (three) characteristics of Street-level Bureaucrats: routine interaction with community, occupation independency and potential impact on the community. Street-level Bureaucrats establish routine interaction with service user community. Interaction is established by building a harmonic relation with community. Libsky (1969) states that "He is called upon to interact constantly with citizens in the regular course of his job". Street level bureaucrat is also given freedom to play its role. Discretion is opened widely to cope with many problems occurring within society. Libsky (1969) states "Although he works within a bureaucratic structure, his independence on the job is fairly extensive. Street level bureaucrat should also exert constructive effect on community. Community independence becomes one of potential expected effects. The potential impact on citizens with whom he deals is fairly extensive" (Libsky, 1969). Considering this characteristic of street level bureaucrats suggested by Libsky, the author analyzes the character of Satlinmas. 


\section{Discussion}

Satlinmas is a form of community protection empowerment. Interior Minister's Decree Number 84 of 2014, in article 1 clause 4, states that the members of satlinmas are Republic of Indonesia citizens eligible and participating voluntarily in community protection activity. The existence of satlinmas becomes a form of collaborative governance. Ansell and Gash (2008) defines collaborative governance, as "A governing arrangement where one or more public agencies directly engage non-state stakeholders in a collective decision-making process that is formal, consensus oriented and deliberative and that aims to make or implement public policy or manage public programs or assets". Satlinmas as the front line related directly to the society has proximity to local community. The proximity to society becomes a means of exploring a variety of existing problems. Satlinmas' proximity to society is build and accompanied with the local wisdom values. Keraf (2002) states that local wisdom is any form of knowledge, belief, conception, or insight and custom or ethics guiding human behavior in living within ecological community. In similar vein, Rahyono (2007) states that local wisdom is human intelligence the certain ethnic groups have and acquire through society experience. These values grow within society and become a means of interacting with each other. This value implantation, among others, encourages Satlinmas' acceptability to society. Departing from this, the objective of Satlinmas' existence is expected to be achieved with the society's welcome. In addition, remaining to bring these noble values with themselves is expected to maintain the community in its order.

The noble values held on by Satlinmas are, among others: "Tenterem iku saranane urip ana ing dunyo, and andap asor". Satlinmas is a means of creating tranquility in society as tranquility is the precondition of living in the world. In a quiet area condition, people will do their daily activities easily without fear and threat. Satlinmas undertakes their duty with "andap asor" (humility). It helps all classes of society readily, treats everyone friendly and is not arrogant.

Satlinmas as street-level bureaucrats has three important characteristics as suggested by Lipsky. Lipsky mentions 3 (three) characteristics of street-level bureaucrats: routine interaction with community, occupation independency and potential impact on the community. These characteristics are inherent to Satlinmas in undertaking its duty. The followings are the characteristics of Satlinmas as Street Level Bureaucrats, according to Lipsky:

\section{Routine Interaction with Community}

The first characteristic of Street-Level Bureaucrats is routine communication with community. " "He is called upon to interact constantly with citizens in the regular course of his job" Lipsky (1969). Communication becomes an important factor in the success of Satlinmas. Communication is conducted directly and intensely with the members of community. Communication conducted by Satlinmas considers the local wisdom values. Putu Oka Ngakan in Andi M Akhmar and syarifudin (2007) mentions that local wisdom is local community's order value or life behavior in interacting wisely with their neighborhood. These values are important in establishing a good communication with community.

Local wisdom values in Satlinmas are, among others: "Titikane aluhur, alusing polah tingkah budi bahasane lan legawane ati, darbe sipat berbudi bawaleksana" meaning that the 
characteristics of lofty people are: their deed and inner attitude are fine, their speech is wellmannered, graceful, and prestigious and having noble character. Interaction with community is based on etiquette and respect. The use of Javanese language becomes a medium of interaction. Javanese language order distinguishing language levels in its use become a means of respecting the people by their age. It warns the community with good manner and noble character. These values are reflected on any role assumed by Satlinmas.

Routine communication can be seen from Satlinmas undertaking its role in helping the disaster coping attempt. The form of local wisdom in communication with community can be seen in educating the community about flood disaster. This flood disaster is frequently due to the overflow of Bengawan Solo River crossing Surakarta City. In controlling and mitigating the effect of flood, Satlinmas gives information actively about maintaining river cleanliness. The members of Satlinmas conduct mobile patrol to remind and to reprimand the citizens disposing rubbish into the river. A Javanese proverb says, " "memayu hayuning bawono" or maintaining the nature as a form of appreciating environment and preventing disaster from occurring. Satlinmas is always also alert when water condition begins to rise and be vulnerable to flood. In conducting this activity, Satlinmas cooperates with the local community. Satlinmas held on Javanese philosophy, "Yitno luwana leno keno" meaning that being careful will be safe, being careless will be unlucky.

Intensive communication can be seen as well from Satlinmas undertaking its role in helping create security and orderliness within society. Article 1 of Republic of Indonesia's Police Law Number 2 of 2002 mentions that the definition of Kamtibmas (community security and orderliness) is a dynamic condition of community as one of requirements for the implementation of national development process in the attempt of achieving the national objective as characterized with the ensured security, orderliness, and law enforcement, and the established tranquility containing the ability of building and developing the community's potency and power in warding off, preventing, and coping with any form of legal infringement and other annoyance forms that can make the community restless. Satlinmas conducts mobile patrol routinely and reminds the citizens to safeguard their own houses, based on the Javanese philosophy "Tumrape wong linuwih tansah mgumdi keslametan liyan, metu soko atine dewe" meaning that the well-off people always attempt to safeguard their fellow's safety from their personal pure intention. Satlinmas safeguards its own neighborhood voluntarily.

Satlinmas also promotes communication in maintaining orderliness, for example, in ordering the Street Sellers (PKL) in Surakarta City. Street Seller Ordering is so far identical with the officers' violence. In this case, Satlinmas prefers using humanism approach and avoiding violence, or in Javanese term "“"nguwongke uwong” meaning humanizing human beings. It is in line with the concept of human governance in Public Administration Science Paradigm. Salleh and Ahmad (2010) mention that this human governance approach is vital and should be the part of implementation and consideration of ethical behavior.

The members of Satlinmas promote discussion, negotiation, and compromise first, using persuasive approach by educating the community about government (public) policy. Enroth (2014) in his article entitled "Governance: The art of governing after governmentality" mentions that governance approach emphasizes more on the attempt of solving public problems, than on developing policy for the community only. Fisher and 
Forester (2002) also shows that the process of planning a policy program relying on interaction and discussion pattern building mutual consensus can have implication to a variety of value positions, develop mutual responsibility in concrete situation, and shows the importance of conflict in the society. Satlinmas can help the sellers fix their stalls without violence.

Satlinmas also applies an effective communication approach in helping organize the societal activity. One of Satlinmas' roles closest to community is to help organize societal activities. Mac Iver and Page in Soekanto (2007) suggest that community is a system of habit and etiquette or procedure, authority and cooperation between groups and categories, and supervision over human behavior and freedoms.

Community is a social relation tie, and community always changes (Soekanto, 2007). A community is actually an adaptive system, as it is a vehicle of fulfilling a variety of interests and of course of surviving. Community also has various needs to meet in order to survive. For that reason, society always cooperates and lives adjacently. Satlinmas as a member of community always engages in various activities. The participation of Satlinmas in societal activities can be seen, among others, in condolence and wedding events. Satlinmas also contributes to organize security in those events. They work without any reward from the community, in Javanese philosophy called "Rame ing gawe sepi ing pamrih".

\section{Occupation independency}

The second characteristic of street-level bureaucrats is independency. Libsky (1969) mentions "Although he works within a bureaucratic structure, his independence on the job is fairly extensive." It means that although Street-level Bureaucrats is on bureaucratic structure, it has independency in undertaking its duty. Satlinmas is a community protecting organization under Satpol PP (Public Order Enforcers)'s supervision. Based on Surakarta Mayor's Regulation Number 7 of 2017, Satlinmas is located in Sub District and responsible to Satpol PP. Satlinmas at Sub District level then establishes linmas (community protector) units at every kelurahan (village). The chairperson of Satlinmas ex-officio is occupied by the head of sub district (camat). The Daily Executive Chairperson of Community Protection at Sub District level is ex officio occupied by the Chairperson of Tranquility and Orderliness Section in Sub District. The Daily Executive Chairperson of Community Protection at Kelurahan level is occupied by the Head of Village (Lurah) and can be delegated to the Chairperson of Government and Orderliness Section in Kelurahan.

Satlinmas is the part of Satpol PP that should, of course, work corresponding to the procedure specified by Satpol PP. Nevertheless, Satlinmas is given right and independency to undertake its duty. The form of Satlinmas' independency can be seen in several discretions taken in solving problems. It is in line with Libsky (1969) stating that "One component of this independence is discretion in making decisions; but independence in job performance is not limited to discretion. The attitude and general approach of a Street-level Bureaucrat toward his client may affect his client significantly. These considerations are broader than the term discretion suggests." It means that one component of independence is discretion in decision making, but independence in working performance is not limited to discretion. Attitude and general approach of Street-Level Bureaucrat to its client can influence its client significantly. This consideration is broader than the one recommended by the term discretion. 
The problem of its limited members leads Satlinmas to think its own way of solving this problem. The members of Satlinmas hired and inaugurated by Satpol PPP so far has not been able to meet the standard minimum service. In one neighborhood association (Rukun Tetangga, thereafter called RT), ideally there is one Linmas, but this has not been implemented yet so that Satlinmas at village level (Satlinmas desa) hires its new member to meet the standard minimum. These members are hired by Head of Village (lurah) and without legal decree (Surat Keputusan, thereafter called SK) of Satpol PP. The recruitment of Satlinmas conducted independently by kelurahan impacts on the amount of honor received. The solution offered for the sake of justice feeling is that the members of Satlinmas should share their honor with other members having no legal decree of Satpol PP.

\section{Potential Impact on the Community}

The third characteristic of Street-level bureaucrats is potential impact on the community. Lipsky (1969) suggests that: "The potential impact on citizens with whom he deals is fairly extensive." The existence of Satlinmas is desirable to help TNI (Indonesian Army) and POLRI (Indonesian Police) in undertaking their duties. Satlinmas as street-level bureaucrats is closer and gives service directly to the community, thereby can understand better the condition and the problem of surrounding environment. Through this understanding, the need and the appropriate security system can be conceived and implemented more easily. Socialization and implementation of policy can be done more easily with the agents that have been dispersed from Neighborhood Association (RT) level. The existence of Satlinmas also impacts considerably on the earlier detection and management of disaster and social vulnerability.

Satlinmas is a big power to create community orderliness and security. The members of Satlinmas can, of course, be empowered and utilized efficiently to fill in the vacuum that is unreachable to TNI, POLRI, and BPBD, and Satpol PP to cater to the community quickly, appropriately, and directly. In the presence of Satlinmas, security is expected to be supervised more closely until RT and RW levels.

As we know, TNI has the lowest command line existing at sub district level unit, Komando Rayon Militer (Koramil, Military Rayon Command) led by a Komandan Rayon Militer (Danramil, Military Rayon Commander), and furthermore POLRI has the lowest command line at sub district sector level, Polisi Sektor (Polsek, Sector Police). The two elements of apparatus are in the largest unit form, while TNI and POLRI apparatuses at Kelurahan and village level, Babinsa and Babinkabtimas, consist of individual only, and Badan Penanganan Bencana Daerah (BPBD, Local Disaster Management Agency) is at Regency and City level, while the lowest command line of Satlinmas reaches RT and RW levels. In the presence of Satlinmas command line at RT and RW levels, the number of Satlinmas members will be higher than that of TNI and POLRI, and BPBD members. Such the large number becomes a power and an opportunity, by which a member is given knowledge and skill to implement disaster management in order to reduce and to mitigate the effect of disaster, and to contribute to maintaining community security, tranquility and orderliness, and organizing societal activity. 


\section{Conclusion}

Satlinmas is one of Street-level bureaucracy forms. It is reflected on some characteristics described by Lipsky: interaction with community, occupation independency and potential impact on the community. Satlinmas interacts with community continuously. Satlinmas also has independence in undertaking its duty. Although Satlinmas is under Satpol PP's supervision, it remains to have authority of solving problem. Satlinmas, as a street-level bureaucracy, has potential impact, citizen's independence in organizing community security and orderliness. As Street-Level bureaucracy, Satlinmas upholds local values in implementing its role will be more acceptable and close to community.

\section{References}

Akhmar, Andi M, Syarifudin. (2007). Mengungkap Kearifan Lingkungan Sulawesi selatan. Makasar: Masagena Press

Ansell C \& Gash A. (2006). Collaborative Governance in Theory and Practice. Working paper research in progress. Berkeley: Department of Political Science. University of California.

Denhard, Janet V \&dan Robert B. Denhard, 2003. The New Public Service, Serving, not Steering. England: M.E. Sharpe.

Enroth, Henrik. (2014). Governance: The art of governing after governmentality, European Journal of Social Theory, 17(1), 60-76.

Fisher, Frank \& John Forester. (2002). The Argumentative Turn in Policy Analysis and Planning. London: Taylor\&Francis e-Library

Geriya, I, W. (2004). Nilai Dasar, Nilai Instrumental dan Referensi Hukum dalam Kearifan Lokal Daerah Bali. Majalah Kerta Wicaksana. Denpasar: Fakultas Hukum Universitas Udayana

Keraf, S. (2002). Etika Lingkungan Hidup. Jakarta: Penerbit Kompas

Lipsky, Michael. (1969). Toward A Theory of Street-level Bureaucrats. New York: University of Wisconsin

Marfai, M.A. (2012). Pengantar Etika Lingkungan dan Kerifan Lokal. Yogyakarta. Gadjah Mada University Press.

Nawawi, Zaidan. (2007). Analisis tentang Profesionalisme Aparatur Pelayanan Publik di Era Otonomi Daerah. Palembang: Universitas Sjakhyakirti

Rahyono, FX. (2009). Kearifan Budaya dalam Kata. Jakarta: wedatama

Salleh, A. and A. Ahmad. (2010). Human Governance:Bringing the meaning of integrity in the life of professional accountants.

Seigler, D. (2011). Renewing democracy by engaging citizen in shared governance. Public administration review, 968-70

Soekanto, Soerjono. (2007). Sosiologi Suatu Pengantar. Jakarta: PT Raja Grafindo. 